\author{
Anna BARWIŃSKA-MAŁAJOWICZ \\ Bogusław ŚLUSARCZYK ${ }^{2}$
}

\title{
CONDITIONS AND BARRIERS TO THE DEVELOPMENT OF ENTREPRENEURSHIP IN POLAND AT THE LOCAL LEVEL
}

\begin{abstract}
Entrepreneurship is a complex and multi-dimensional phenomenon, as evidenced by multiple studies of the subject within the field of economics, as well as other sciences. An important problem in the development of entrepreneurship is identification of barriers that significantly block this process. The main purpose of this study is to present conditions and barriers in the development of entrepreneurship in Poland on a local scale, based on the example of two poviats located in the Podkarpackie voivodeship (Krosno and Jasło poviats). The main methods adopted for the purposes of this study were: desk research method and descriptive and statistical analysis of research results obtained from a diagnostic survey conducted among entrepreneurs operating in Krosno and Jasło poviats. The obtained results were subjected to statistical analysis using descriptive statistics methods, including chi-square independence test (Pearson's chi-square test). The paper provides findings from the research and a theoretical model describing entrepreneurship and its determinants.
\end{abstract}

Keywords: entrepreneurship, entrepreneurship barriers, pre-entrepreneurial behavior.

\section{INTRODUCTION}

Entrepreneurship is a very broad interdisciplinary issue. It is a complex and multidimensional phenomenon, as evidenced by the literature studies of the subject developed in the field of economics as well as other sciences (management, psychology, sociology). The development of entrepreneurship is influenced by a number of factors dependent on the one hand on the personality predispositions of the entrepreneur, and on the other - external conditions, in which the entrepreneurship process is carried out. An important problem in the development of entrepreneurship is identification and then overcoming barriers that significantly block this process.

The main purpose of this study is to present the conditions and barriers to the development of entrepreneurship in Poland on a local scale, based on the example of two poviats located in the Podkarpackie voivodeship (Krosno and Jasło poviats). The main

\footnotetext{
${ }^{1}$ Anna Barwińska-Małajowicz, DSc, PhD, Associate Professor, Institute of Economics and Finance, University of Rzeszów, ul. Ćwiklińskiej 2, 35-601, Rzeszów; e-mail: effib@o2.pl (corresponding author). ORCID 0000-0002-0228-1761.

2 Bogusław Ślusarczyk, DSc, PhD, Associate Professor, Institute of Economics and Finance, University of Rzeszów, ul. Ćwiklińskiej 2, 35-601, Rzeszów; e-mail: boguslaw.slusarczyk@gmail. com. ORCID: 0000-0003-0567-8470.
} 
methods adopted for the purposes of this study were: desk research method and descriptive and statistical analysis of research results obtained as a result of a diagnostic survey conducted among entrepreneurs operating in the Krosno and Jasło poviats. The results were subjected to statistical analysis using descriptive statistics methods, including chi-square independence test (Pearson's chi-square test). The first part of the study presents the essence of entrepreneurship and its determinants. The second part analyzes conditions for the development of enterprises on a local scale based on selected own research results. The whole paper ends with a synthetic summary of the analyses and considerations carried out.

\section{THE ESSENCE OF ENTREPRENEURSHIP AND ITS DETERMINANTS}

Entrepreneurship as an economic category is currently becoming the subject of discussion of representatives of many scientific disciplines, including economics, organization and management, sociology, ethics, psychology and business economics. This means that it is interdisciplinary and has no universal definition (Dębska, Ślusarczyk, 2010). Difficulties in defining it also arise from the fact that the concept of entrepreneurship is subject to constant evolution, which takes place under the influence of changes in the conditions of business entities.

In economic theory, entrepreneurship is defined as a particular type of skill and job, or also as the fourth factor of production, next to work, land and capital. On one hand, it is a specific way of dealing with people, which is revealed by a certain set of features (Kumasz, 2009, Barwińska-Małajowicz, 2016), while on the other, the process of creating and building something new (e.g. an enterprise). It also manifests itself in the constant search for modern business opportunities. Many authors in their concepts pointed to various aspects of entrepreneurship ${ }^{3}$. However, everyone agreed that entrepreneurship is a unique concept - a unique attitude, unusual behavior, which plays a special role in the economy, especially in the market (but not only). It is inextricably linked to the development of economic life, undertaking business activities and activities of individual individuals, social groups and organizations with certain predispositions, skills and characteristics.

Entrepreneurship is therefore a multidimensional and complex concept, consisting of at least three categories, namely: entrepreneurship as an attitude, entrepreneurship as behavior and entrepreneurship as a process. Specified components of this concept intertwine and complement each other. However, today, the process approach is recognized as one of the most important principles in the field of management and organization of modern economic entities. Entrepreneurship is crucial for their economic development and functioning. It should also be noted that entrepreneurship is not only a behavior, attitude or trait, but also all economic, personality, political and legal circumstances favorable to entrepreneurial attitudes. These circumstances are found in organizations, people and, above all, macro environment.

\footnotetext{
${ }^{3}$ Concepts of the following authors: J. Schumpeter, E. Kirzner, F.H. Knight indicated various aspects of the enterprise, namely: J. Schumpeter treated it as a process of creative destruction, that the moving spirit are innovations in a broad meaning; E. Kirzner pointed that the enterprise is the ability of using differences on markets, whereas F.H. Knight stated that the category is connected with the risk undertaken in economic activity, and profit is simply entrepreneur's payment for predictions' accuracy.
} 
The analysis of entrepreneurship conditions should be particularly focused on researching the institutional context, the task of which is to determine the entrepreneurial potential of a given country or region. There are two dimensions that make up the institutional profile of a country or region (Pyka, 2007):

- cognitive - related to the skills that people have in a given country or region, as well as their knowledge necessary to set up and run a business;

- regulatory - covering regulations and provisions of law as well as those applied by central authorities and at the regional level, local policies that generate opportunities to support new businesses, limit the risk and uncertainty associated with starting a business, and facilitate obtaining new financing sources.

The above-mentioned dimensions are undoubtedly crucial for the development of entrepreneurship. Nevertheless, the dynamics of entrepreneurial activities is also affected by a number of factors occurring at the national, regional and local level of external and internal nature. The group of external factors includes: technical status, society's predisposition to change, market situation, compliance with the provisions on freedom and freedom of economic activity, as well as economic, educational, political and ideological factors (Frąckiewicz, Ćwiertnia, 2015). On the other hand, internal factors that shape the development of entrepreneurship are, among others: action strategy, company size, employees' predisposition to innovation, information and organizational determinants of development processes, in particular management style, organizational culture, communication system, level of qualifications as well as management and employees competences.

Summing up the current considerations, it should be emphasized that when analyzing the entrepreneurial process, barriers to the development of entrepreneurial projects aimed at innovation and creativity of the behavior of business entities cannot be ignored. In the literature on the subject, the most frequently mentioned barriers include:

- financial barriers that companies most often encounter when starting a business. They manifest themselves mainly in difficult access to capital that could be obtained for development or in access to bank loans;

- market barriers consisting, among others, in insufficient demand, difficulties in entering the market and gaining new sales markets, weaker market position in comparison with foreign contractors;

- legal and administrative barriers related to the instability and clarity of legal provisions and elements of the tax system;

- social barriers resulting from the lack of a proper work organization system, from low employee mobility and imperfections of the motivation system and career path;

- information barriers manifested in relatively inactive gathering of own market information, in too narrow conducting independent marketing research and using the services of business support agencies or consulting companies to a small extent (Zdrajkowska, Zakrzewska-Bielawska, 2006);

- management and educational barriers, which are related to the inability to adapt to changing environmental conditions, competences of entrepreneurs, insufficient knowledge and small amount of training and vocational training programs regarding exploration of opportunities and threats arising in the environment. 
There is no doubt that knowledge of emerging internal and external difficulties is important, as identifying them allows the application of appropriate measures necessary to overcome them in economic practice at all levels, especially at local level.

\section{CONDITIONS FOR THE DEVELOPMENT OF ENTERPRISES ON A LOCAL SCALE - ANALYSIS OF OWN RESEARCH RESULTS}

Entrepreneurship is of great importance for economic growth, the functioning of the organization and the development of employees. This phenomenon can be considered in three dimensions: national economy, enterprise (or institution) and in the dimension of the human individual. Similarly, determinants and conditions for the development of entrepreneurship can be analyzed at the national level, on a regional or local scale.

In further part of the study, results of the entrepreneurship research and determinants of its development at the local level were analyzed (on the example of the Jasło and Krosno poviats located in the Podkarpackie Voivodeship). The research was conducted at the turn of 2018/2019 using the diagnostic survey method and applying a questionnaire. Onehundred-six enterprises took part in the study (62 respondents were representatives of enterprises operating in the Jasło poviat and 44 in the Krosno poviat). Selection of the research sample was deliberate. The questionnaire was sent to enterprises electronically. It contained 33 closed (single and multiple choice) and semi-open questions. The research was anonymous. The obtained results were subjected to statistical analysis using descriptive statistics methods, including chi-square independence test (Pearson's chi-square test) in order to examine the relationship between the two selected nominal (categorical) variables.

Majority of business entities participating in the survey were micro-enterprises (including 46 companies in Jasło and Krosno poviats, which constituted $43 \%$ of the total number of respondents). Not much less - 41\% (43 companies) - were small enterprises, while $15 \%$ (16 companies) were medium-sized enterprises. The least responses were received from large enterprises employing over 250 people (only $1 \%$ - only one large enterprise operating in the Krosno poviat responded to the questionnaire) (Table 1).

The survey involved both partnerships and capital companies, with the majority of surveyed enterprises operating in the form of a sole proprietorship (together from both poviats, $42 \%$ of all respondents provided such answers). In turn, $24 \%$ of all surveyed companies have the form of limited liability. The share of entities operating in the form of a company was $13 \%$, joint stock $-9 \%$. Each $5 \%$ of the surveyed companies operate as a civil law partnership. The least - only $2 \%$ of respondents - declared the form of a limited partnership (Table 1).

Analysis of research results indicates that just over $2 / 5$ of respondents (43\%) have been on the market for over 10 years. In turn, 30 companies (28\%) have been operating for 6-10 years, while $25 \%$ have been operating on the market for $1-5$ years. Only $4 \%$ of the surveyed enterprises have been operating for less than 1 year (Table 1).

Question about the nature of industry, in which the surveyed companies operate was semi-open. The respondents had the opportunity to choose from among several given answer options as well as free speech. Most companies surveyed operate in the service industry (29 enterprises), in construction (18), industry (17) and trade (12). The least respondents declared that they run a business in tourism, IT and health care ( 2 enterprises each) and telecommunications ( 1 enterprise). Most - almost 4/5 of the surveyed enterprises - operate on a regional or local basis (49 and 30 companies, respectively) (Table 1). 
Conditions and barriers ...

Table 1. Profile of surveyed enterprises (number)

\begin{tabular}{|c|c|c|c|}
\hline & Jasło poviat & Krosno poviat & Total \\
\hline \multicolumn{4}{|c|}{ Enterprise size } \\
\hline Micro-enterprises & 25 & 21 & 46 \\
\hline Small enterprises & 30 & 13 & 43 \\
\hline Medium enterprises & 7 & 9 & 16 \\
\hline Large enterprises & 0 & 1 & 1 \\
\hline \multicolumn{4}{|c|}{ Organizational and legal form of the surveyed enterprises } \\
\hline sole proprietorship & 23 & 22 & 45 \\
\hline limited liability company & 18 & 7 & 25 \\
\hline general partnership & 5 & 9 & 14 \\
\hline joint-stock company & 8 & 2 & 10 \\
\hline partnership & 2 & 3 & 5 \\
\hline civil law partnership & 4 & 1 & 5 \\
\hline limited partnership & 2 & 0 & 2 \\
\hline \multicolumn{4}{|c|}{ Period of operation of the surveyed enterprises in the market } \\
\hline over 10 years & 29 & 17 & 46 \\
\hline $6-10$ years & 15 & 15 & 30 \\
\hline $1-5$ years & 15 & 11 & 26 \\
\hline less than 1 year & 3 & 1 & 4 \\
\hline \multicolumn{4}{|c|}{ Sector } \\
\hline services & 16 & 13 & 29 \\
\hline civil engineering & 12 & 6 & 18 \\
\hline industry & 11 & 6 & 17 \\
\hline trade & 4 & 8 & 12 \\
\hline commercial and service & 4 & 6 & 10 \\
\hline production & 7 & 0 & 7 \\
\hline finance and insurance & 4 & 2 & 6 \\
\hline tourism & 0 & 2 & 2 \\
\hline informatics & 1 & 1 & 2 \\
\hline healthcare & 2 & 0 & 2 \\
\hline telecommunication & 1 & 0 & 1 \\
\hline \multicolumn{4}{|c|}{ Range of conducted activity } \\
\hline local & 20 & 10 & 30 \\
\hline regional / provincial & 25 & 24 & 49 \\
\hline nationwide & 11 & 5 & 16 \\
\hline international & 6 & 5 & 11 \\
\hline
\end{tabular}

Source: own study.

Creating a climate favorable to the development of entrepreneurship is one of the company's important goals. Building of this climate is influenced by a number of external and internal factors. A properly shaped climate and entrepreneurial culture favors entrepreneurial behavior. 


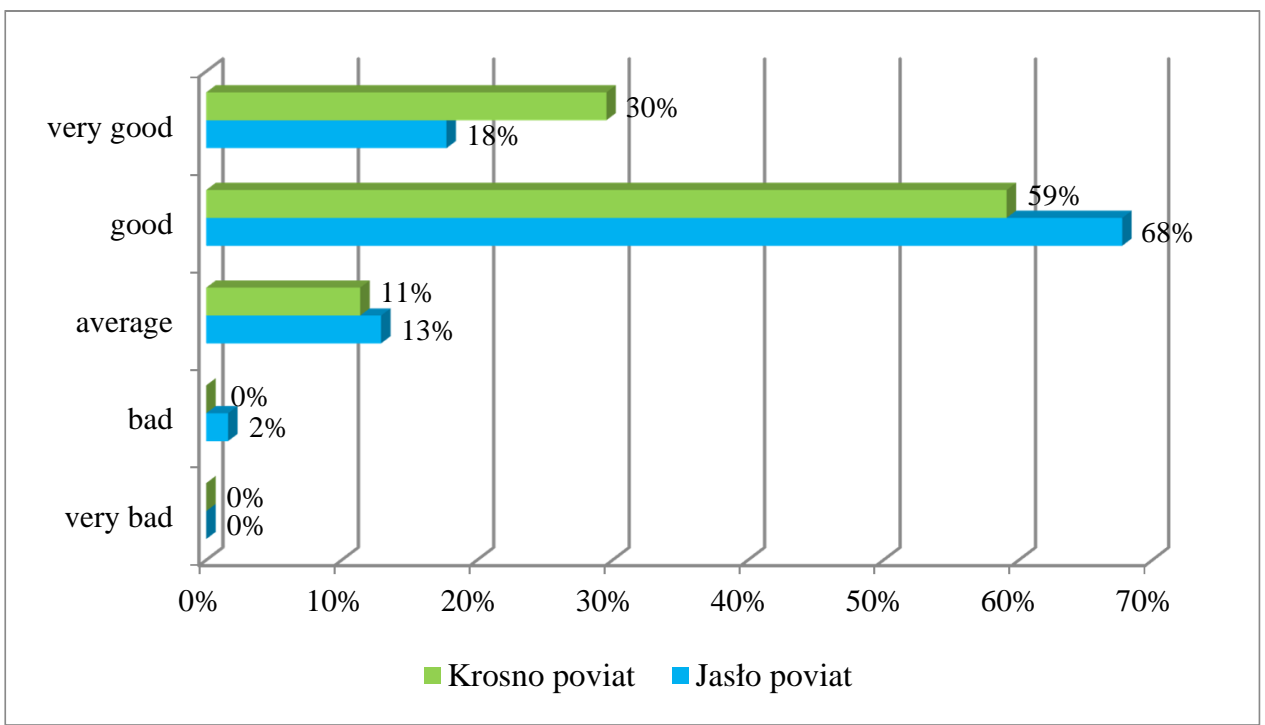

Fig. 1. Enterprise climate assessment

Source: own study.

Analysis of data presented in Fig. 1 shows that in both surveyed poviats, the entrepreneurship climate prevailing in the surveyed companies was assessed relatively high. In both the Krosno and Jasło poviats, almost $90 \%$ of companies gave a very good or good grade in this respect ( $89 \%$ and $86 \%$, respectively). Only slightly more than $10 \%$ of enterprises rated the enterprise climate prevailing at an average level $(13 \%$ in the Jasło poviat, not much less in Krosno, 11\%).

Entrepreneurship depends not only on many different factors, but "is the result of a combination of various conditions, depending both on the internal predispositions of specific individuals undertaking the enterprise and on the external conditions, in which the entrepreneur (organization) operates" (Huczek, 2009). The literature on the subject divides these factors into internal organizational and environmental factors (Kraśnicka 2002).

As the analysis of data compiled in Fig. 2 shows, the assessment of factors influencing the creation of an appropriate climate for the development of entrepreneurship in each of the surveyed poviats is slightly different. In the Jasło poviat, the respondents considered the factors supporting innovation to be the most important group of factors influencing the creation of an appropriate climate for the development of entrepreneurship $(79 \%$ of surveyed enterprises). In subsequent places, enterprises indicated attitudes and policies of the government and local authorities towards changes in the enterprise (65\% of responses) and attitudes of entrepreneurial people towards changes in the enterprise $(58 \%$ of respondents). In turn, Krosno companies considered the most important group of factors to be attitudes of entrepreneurial people towards changes in the enterprise ( $77 \%$ of responses). Slightly fewer indications were noted for factors supporting innovation and attitudes as well as policy of the government and local authorities towards changes in the enterprise $(73 \%$ and $68 \%$ of respondents, respectively). 


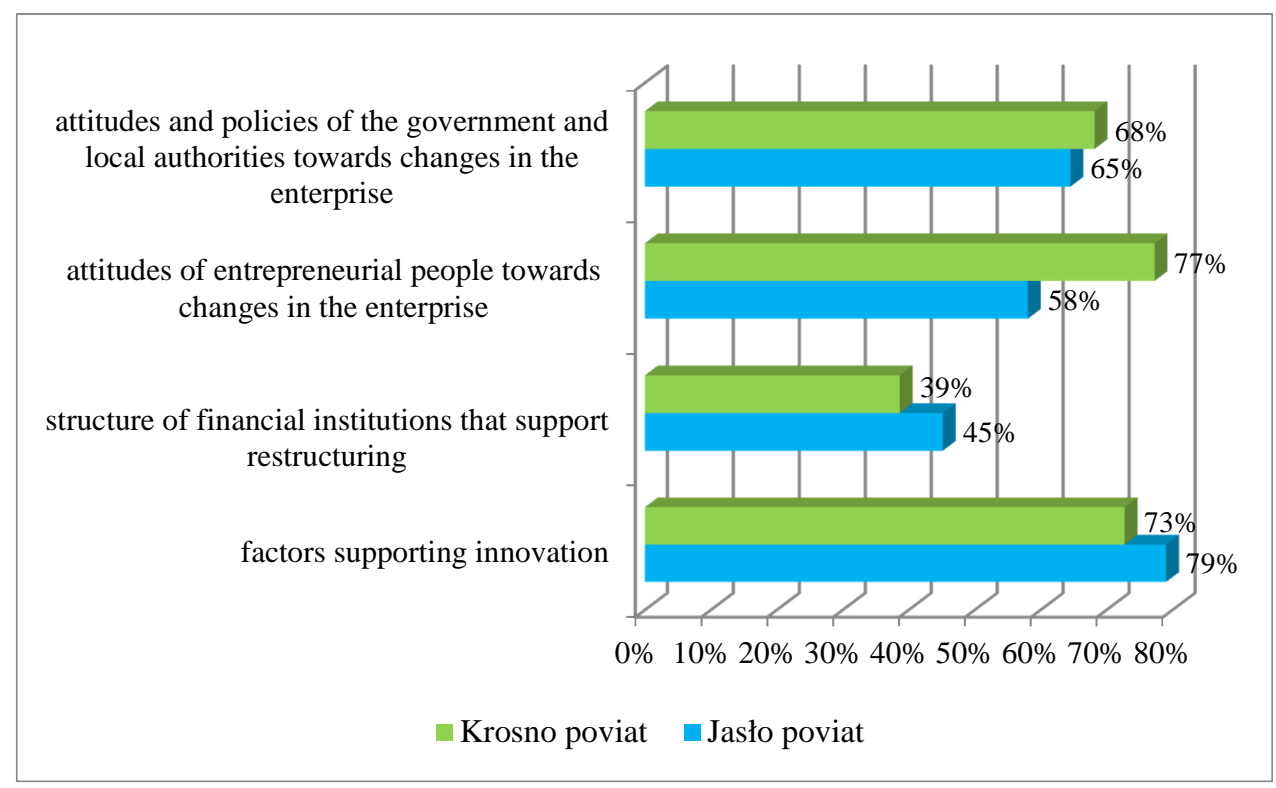

Fig. 2. Factors influencing the creation of an appropriate climate for the development of entrepreneurship

Source: own study.

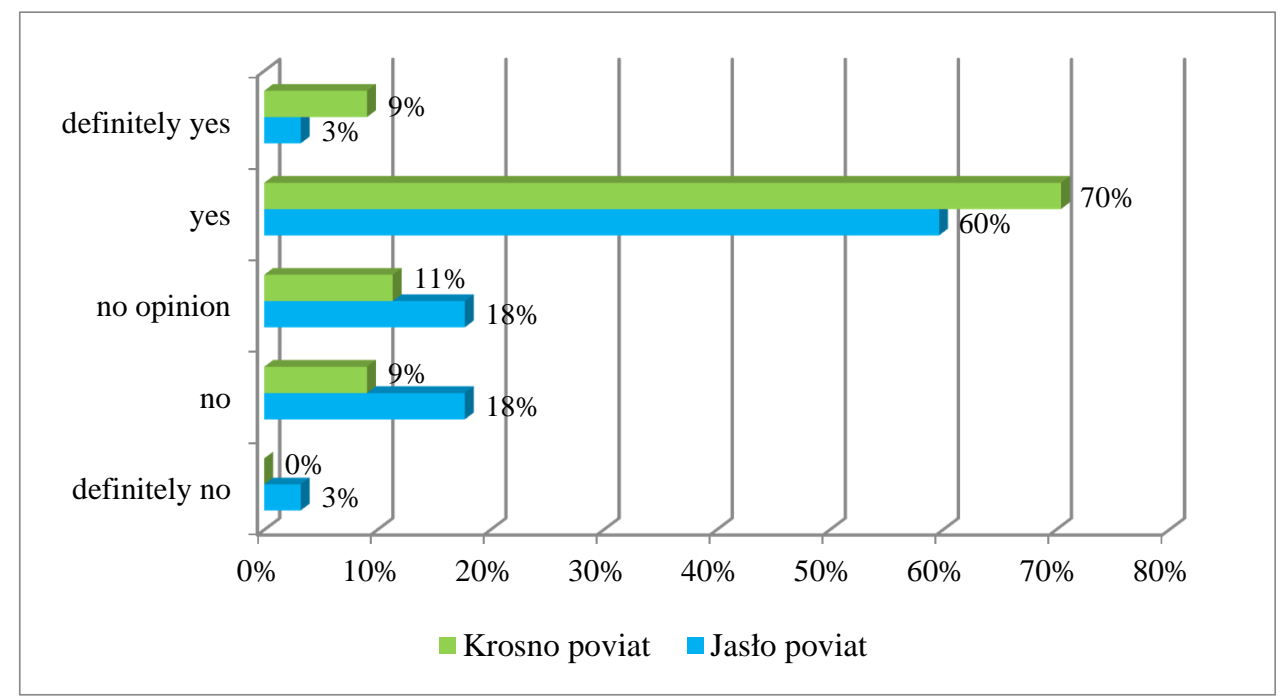

Fig. 3. Impact of environmental values on entrepreneurship development

Source: own study.

As part of the study on entrepreneurship development conditions, respondents were also asked to assess the impact of environmental values on entrepreneurship development. The 
majority of enterprises from both examined poviats declared that environmental values have a positive impact on the development of entrepreneurship (63\% of enterprises from the Jasło poviat, and $79 \%$ of enterprises from the Krosno poviat, and 3\% of enterprises from the Jasielski poviat and 9\% from the Krosno poviat responded with the answer: "definitely yes". Relatively many respondents did not have an opinion in this respect (18\% of the surveyed Jasło companies and $11 \%$ of Krosno companies). Among the respondents, there were also organizations that believed that environmental values did not have a positive impact on the development of entrepreneurship (21\% of companies from the Jasło poviat and $9 \%$ from the Krosno poviat, while not one company from the Krosno poviat did not indicate the answer: "definitely no"; such an answer was declared by $3 \%$ of enterprises from the Jasło poviat). Such a high assessment of the impact of environmental values on the development of entrepreneurship may result from the strong bond of companies with the local environment and the implementation of e.g. joint projects and strategic goals. Not without significance for the development of entrepreneurship is the support of entrepreneurs by local authorities, which was mostly positively assessed.

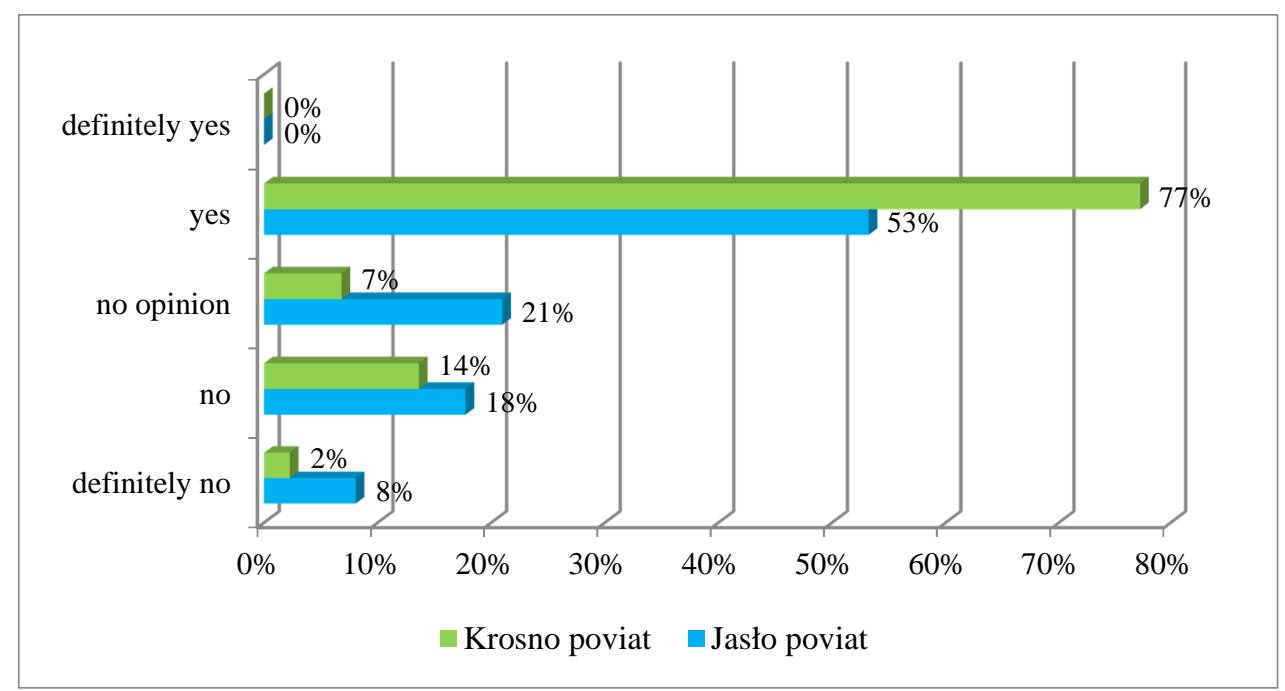

Fig. 4. Assessment of support for enterprises in the scope of entrepreneurial activities by local authorities

Source: own study.

The analysis of data presented in Fig. 4 indicates that 53\% of the surveyed entrepreneurs from the Jasło poviat and as much as $77 \%$ from the Krosno poviat highly rated the support of local authorities. As many as $21 \%$ of the respondents of the Jasło poviat and $7 \%$ of the Krosno poviat did not express their opinion on this subject. The percentage of respondents who rated the activities of local authorities negatively $(26 \%$ of the surveyed entrepreneurs from the Jasło poviat and 16\% from the Krosno poviat, including the answers: "definitely no" responded by $8 \%$ and $2 \%$ respondents, respectively). It can be assumed that in many cases, cooperation between entities and the commune brings measurable benefits, however, 
there are also some shortcomings in this respect. In the opinion of the surveyed entrepreneurs, local authorities should therefore take actions that will be focused on supporting the entrepreneurial activities of companies located in the surveyed poviats.

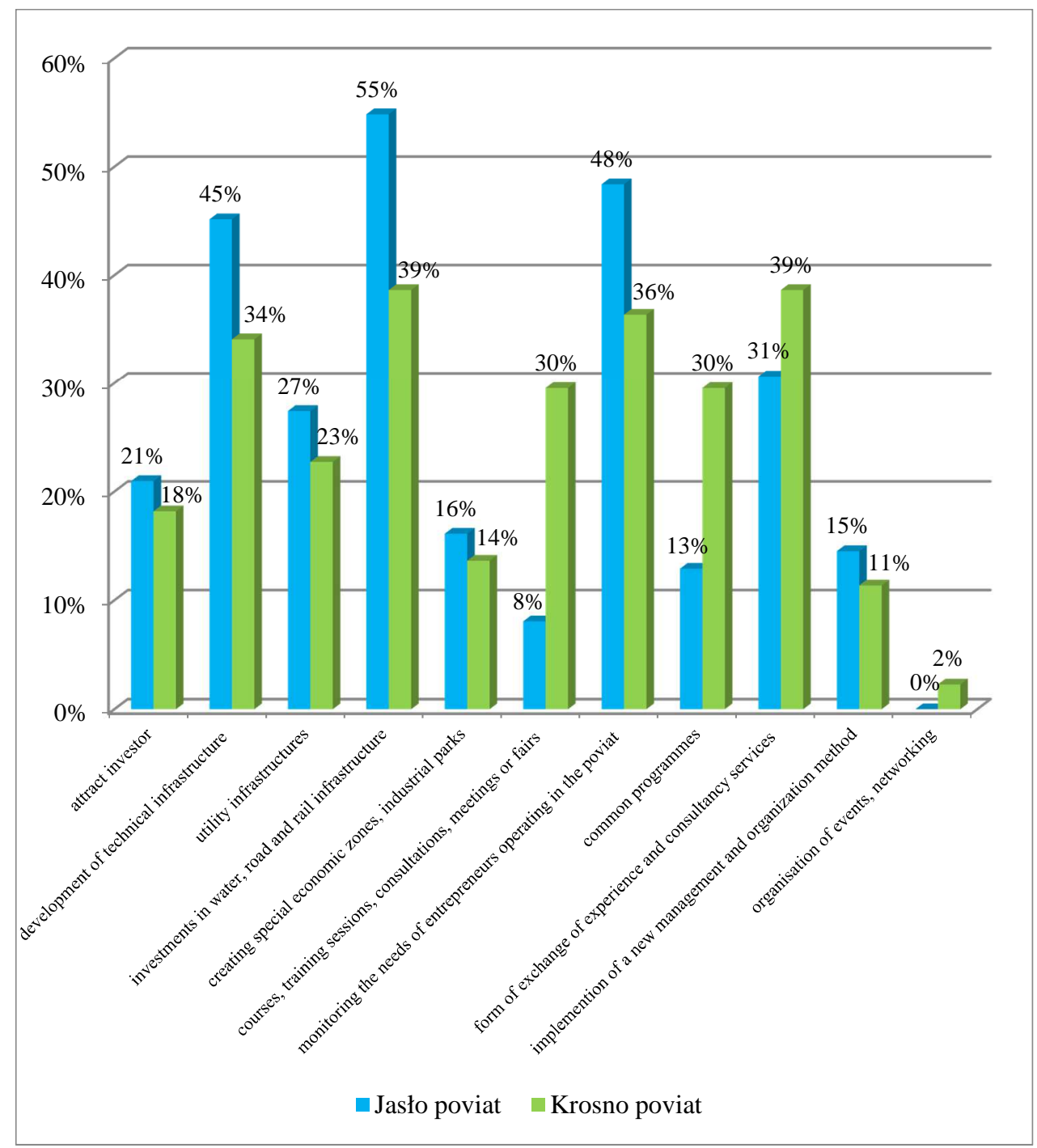

Fig. 5. Types of actions that local authorities should take to develop entrepreneurship Source: own study.

Analysis of data summarized in Fig. 5 shows both similarities and some differences in the assessment of entrepreneurs depending on the poviat, in which their companies operate. Entrepreneurs in both poviats declared that the most important type of support for local 
authorities should be investments in water, road and rail infrastructure. In the Krosno poviat, the need for support in the form of exchange of experience and consultancy services was rated equally high, while monitoring the needs of entrepreneurs operating in the poviat and the development of technical infrastructure were followed in both places. It is noteworthy that, in the opinion of entrepreneurs from the Krosno poviat, it would also be very important to support the authorities in the form of organizing courses, training sessions, consultations, meetings or fairs (30\% of responses), which, in turn, according to the respondents from the Jasło poviat, was not considered desirable (8\% answers).

The concept of innovation is associated with entrepreneurship. The basis for linking the two conceptual categories are the views of J. Schumpeter, who treated innovation as a factor in economic development. He perceived innovations as new combinations occurring, for example, in the case of creating a new product (or launching goods with new properties) or in the case of introducing new production methods, acquiring new markets, obtaining new sources of raw materials, creating new, more effective organizational forms of business activity (Schumpeter, 1960). According to these views, entrepreneurship is directly linked to innovation, leads to innovation and technological change, thus contributing to economic growth.

A review of the literature on the subject indicates the existence of many barriers to the innovativeness of enterprises that occur both on the side of the environment of enterprises and inside them. In connection with the above, the respondents were also asked about the most important barriers to undertaking innovative activities by their enterprises. Analysis of data summarized in Fig. 6 shows differences in perception of barriers in the field of innovation activities. According to the surveyed enterprises from the Jasło poviat, the most important barriers to undertake the innovative activities are too high costs of innovation. This answer was declared by $44 \%$ of the surveyed companies. In the next two places, the respondents of this poviat pointed out: too much risk associated with implementing innovations and difficult access to external sources (35\% and 32\% of enterprises, respectively). Not much less, $31 \%$ of the surveyed companies each, one of the most important barriers is the uncertain demand for innovative products and the lack of interest in new products and services on the part of clients. In turn, entrepreneurs of the Krosno poviat considered the most important barriers to the lack of financing of innovations or their excessively high costs. $41 \%$ of respondents declared such an answer. In second place, there was the lack of plans to implement innovation (36\% of responses). Subsequently, the organizations pointed to high costs of innovation (32\% of respondents). Difficult access to information and a lack of interest in new products and services were slightly lower in the hierarchy (23\% of companies said so). Entrepreneurs of this poviat (similarly to their colleagues from the Jasło poviat) believed that the least important barrier when undertaking innovative activity is the lack of ability to use new technologies.

The distribution of answers to the question regarding support for entrepreneurship by local authorities was compared with the poviat, in which entrepreneurs operate. Table 2 presents distribution of responses divided into poviats (theoretical values calculated using Microsoft Excel 2013). 


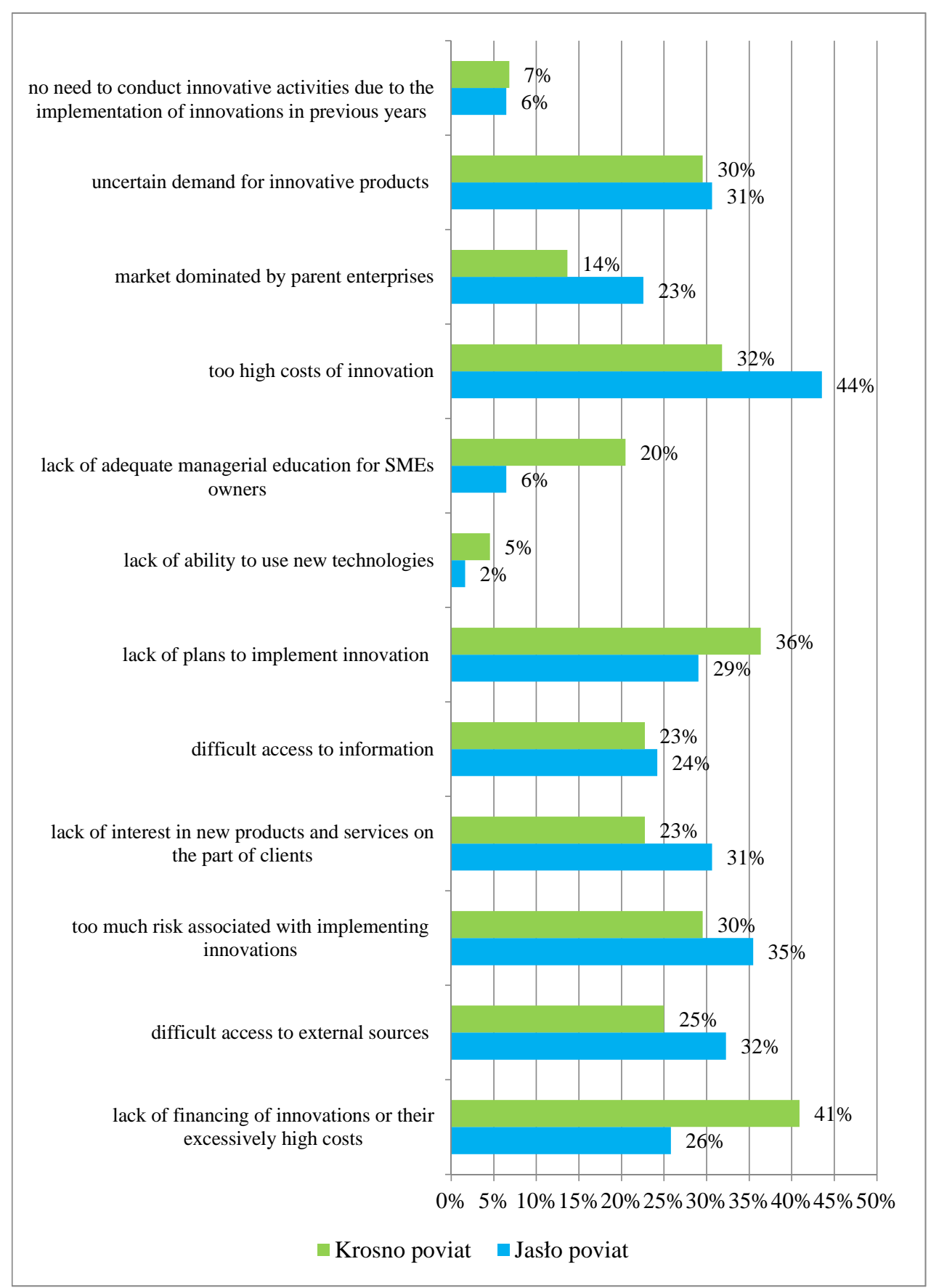

Fig. 6. The most important barriers to undertake innovative activities

Source: own study. 
Table 2. Structure of enterprise responses regarding support for entrepreneurship by local authorities divided into poviats (theoretical values)

\begin{tabular}{|c|c|c|c|c|c|c|}
\hline & definitely not & no & no opinion & yes & $\begin{array}{c}\text { definitely } \\
\text { yes }\end{array}$ & $\mathbf{n}_{\mathbf{j}}$ \\
\hline Jasło poviat & 3,509433962 & 9,943396226 & 9,358490566 & 39,1886792 & 0 & $\mathbf{6 2}$ \\
\hline Krosno poviat & 2,490566038 & 7,066603774 & 6,641509434 & 27,8113208 & 0 & $\mathbf{4 4}$ \\
\hline $\mathbf{n}_{\mathbf{i}}$ & $\mathbf{6}$ & $\mathbf{1 7}$ & $\mathbf{1 6}$ & $\mathbf{6 7}$ & $\mathbf{0}$ & $\mathbf{1 0 6}$ \\
\hline
\end{tabular}

Source: own study.

The chi-square test was used in further analysis. Two hypotheses were made to examine the relationship. The first $\mathrm{H} 0$, called the null hypothesis, assumed that support for entrepreneurship by local authorities is independent of the poviat. It takes the form: $\mathrm{H}_{0}$ : pij = pi. p.j. The second $\mathrm{H} 1$ hypothesis, in relation to the null hypothesis, called an alternative hypothesis, assumed that the support of entrepreneurship by local authorities depends on the poviat. It takes the following form: $\mathrm{H}_{1}$ : pij $\neq$ pi. p.j ..

Table 3. Chi-square test feature values

\begin{tabular}{|c|c|c|c|}
\hline $\mathbf{n}_{\mathbf{i j}}$ & $\mathbf{n} \times \mathbf{p}_{\mathbf{i j}}$ & $\left(\mathbf{n i j}-\mathbf{n} \times \mathbf{p}_{\mathbf{i j}}\right)^{\mathbf{2}}$ & $\boldsymbol{\chi}^{\mathbf{2}}$ \\
\hline 5 & 3,509433962 & 2,221787 & 0,633089876 \\
\hline 1 & 2,490566038 & 2,221787 & 0,892081189 \\
\hline 11 & 9,943396226 & 1,116412 & 0,112276682 \\
\hline 6 & 7,056603774 & 1,116412 & 0,158208052 \\
\hline 13 & 9,358490566 & 13,26059 & 0,416958309 \\
\hline 3 & 6,641509434 & 13,26059 & 1,99662307 \\
\hline 33 & 39,1886792 & 38,29975 & 0,9773167 \\
\hline 34 & 27,8113208 & 38,29975 & 1,37712808 \\
\hline 0 & 0 & 0 & 0 \\
\hline 0 & 0 & 0 & $\mathbf{7 , 5 6 3 6 8 1 9 6 2}$ \\
\hline
\end{tabular}

Source: own study.

For significance $\alpha=0.05$ and $(2-1) \times(5-1)$ degrees of freedom, the critical value of the chi-square distribution is 0.710723021 . The calculated value of test statistics falls into the critical area, hence we reject the $\mathrm{H}_{0}$ hypothesis about the independence of features, because $\chi_{\text {stat }}^{2}>\chi_{\text {crit }}^{2},(7.56>0.71)$. We cannot assume that the features are independent - the features are significantly dependent. We reject the $\mathrm{H}_{0}$ hypothesis in favor of the alternative $\mathrm{H}_{1}$ hypothesis, claiming that the support of entrepreneurship by local authorities depends on the poviat. 


\section{SUMMARY}

When summarizing the conducted considerations and research results, it should be stated that entrepreneurship is a complex and multidimensional category. It can be defined as a skill, a feature of an enterprise, a human being to search for and introduce new solutions. However, this requires ingenuity, energy, initiative, the ability to take risks, as well as responsibility for actions and decisions taken. It is a means of achieving success for both organization (enterprise) and human, and has a key impact on the development dynamics of economic entities, because its essence lies in innovation and creativity.

Development of entrepreneurship depends on both internal and external factors. However, the most important factor is knowledge and information about difficulties preventing the development of entrepreneurship. They make it possible to identify them and overcome them in business practice in every field of their activity, both on a macro- and microeconomic scale. The analysis of research results carried out in this study shows that the level of entrepreneurship of companies is determined by many different factors. Among the most important barriers affecting the entrepreneurship development, respondents pointed to financial difficulties (53\%), frequently changing legal provisions (42\%), and high taxes $(39 \%)$. On the other hand, they see opportunities in the availability of capital resources $(58 \%)$, access to modern technologies $(29 \%)$ or accessibility in communication (96\%). In addition, it was pointed out that business environment institutions play an important role in the development of local entrepreneurship. They provide IT, training, consulting, financial and technical services for people starting a business. They also generate favorable conditions for already operating enterprises and for newly created ones. Entrepreneurship incubators, innovation centers, technology parks, scientific research institutes, technology centers, academic entrepreneurship incubators, special economic zones are one of many business environment institutions. These centers are key stimulators of entrepreneurial ventures and determine the success of undertaken actions.

\section{REFERENCES}

Barwińska-Małajowicz, A. (2016). Przedsiębiorczość absolwentów największych publicznych szkót wyższych $w$ województwie podkarpackim $w$ świetle wyników badań empirycznych. Ostrołęka: Zeszyty Naukowe Wyższej Szkoły Ekonomiczno-Społecznej w Ostrołęce, 4 (23).

Dębska, J., Ślusarczyk, B. (2010). Uwarunkowania przedsiębiorczości we wspótczesnym procesie gospodarowania [w:] Arent, A., red., Zarzadzanie przedsiębiorstwem i regionem wobec wyzwań europejskich. Lublin: Wydawnictwo Politechniki Lubelskiej.

Frąckiewicz, E., Ćwiertnia, A. (2015). Przedsiębiorczość internetowa polskich MŚP a polityka cyfrowa Unii Europejskiej. „Marketing i Rynek”, nr 10.

Huczek, M. (2009). Zarzązanie jako czynnik rozwoju przedsiębiorczości „PrzedsiębiorczośćEdukacja”, nr 5.

Kraśnicka, T. (2002). Koncepcja rozwoju przedsiębiorczości ekonomicznej i pozaekonomicznej. Katowice: Wyd. AE w Katowicach.

Kumasz, M. (2009). Przedsiębiorcze zarządzanie w sektorze MSP. Szczecin: Wydawnictwo Uniwersytetu Szczecińskiego.

Pyka, J. (2007). Przedsiębiorczość i innowacje. Uwarunkowania i czynniki rozwoju. Katowice: TNOiK, Oddział w Katowicach. 
Schumpeter, J.A. (1960). Teoria rozwoju gospodarczego. Warszawa: Wydawnictwo PWE.

Zdrajkowska, H., Zakrzewska-Bielawska, A. (2006). Bariery rozwoju matych i średnich przedsiębiorstw w Polsce $i$ Wielkiej Brytanii [w:] Hejduk, J.K., Korczak, J., red., Gospodarka oparta na wiedzy. Koszalin: Monografia Wydziału zarządzania. Wydawnictwo Politechniki Koszalińskiej.

DOI: $10.7862 /$ rz.2020.hss.12

The text was submitted to the editorial office: December 2019.

The text was accepted for publication: June 2020. 